\title{
Novel mutations in the QRDR region gyrA gene in multidrug-resistance Corynebacterium spp. isolates from intravenous sites
}

\author{
Juliana Nunes Ramos • Talita Bernardo Valadão • Paulo Victor Pereira Baio • \\ Ana Luiza Mattos-Guaraldi • Verônica Viana Vieira
}

Received: 12 June 2019/Accepted: 18 October 2019/Published online: 18 November 2019

(C) The Author(s) 2019

\begin{abstract}
The resistance to fluoroquinolones in corynebacteria is due to mutations occurring in the quinolone-resistance-determining region (QRDR) of the gyrA gene encoding the enzyme gyrase A subunit. In recent years we can observe an increasing number of infections caused by multidrug-resistant $\mathrm{Co}$ rynebacterium striatum, Corynebacterium jeikeium and Corynebacterium urealyticum, including wide range of disorders, such as invasive infections. In this study 14 Corynebacterium spp. isolated from intravenous sites were sequenced and new combinations of
\end{abstract}

J. N. Ramos · T. B. Valadão

Instituto Nacional de Controle de Qualidade em Saúde (INCQS), Fundação Oswaldo Cruz (FIOCRUZ),

Rio de Janeiro, Brazil

J. N. Ramos · P. V. P. Baio · A. L. Mattos-Guaraldi Laboratório de Difteria e Corinebactérias de Importância Clínica (LDCIC), Faculdade de Ciências Médicas, Universidade do Estado do Rio de Janeiro, Rio de Janeiro, Brazil

\section{T. B. Valadão · V. V. Vieira ( $\square)$}

Laboratório Interdisciplinar de Pesquisas Médicas (LIPMED), Instituto Oswaldo Cruz, Fundação Oswaldo Cruz (FIOCRUZ), Av. Brasil, 4365, Pavilhão Cardoso Fontes, 10 andar, sala 17, Manguinhos, Rio de Janeiro, RJ CEP 21040-900, Brazil

e-mail: vieira@ioc.fiocruz.br

P. V. P. Baio

Laboratório Químico-Farmacêutico do Exército (LQFEx), Ministério da Defesa, Rio de Janeiro, Brazil mutations in the QRDR of the gyrA gene were found in C. jeikeium and C. urealyticum. Nowadays, no study comparing mutations in this region and the susceptibility to fluoroquinolones in C. jeikeium and C. urealyticum has been described. All the isolates that showed double mutation (position 87 and 91) in the QRDR gyrA gene had high MIC to the fluoroquinolones tested.

Keywords Corynebacterium $\cdot$ Multidrugresistance $\cdot$ Fluoroquinolones $\cdot$ gyrA mutation · QRDR

The antibiotic resistance among Corynebacterium species has increased, sometimes leading to the use of vancomycin as the drug of choice (Yoo et al. 2015). Some Corynebacterium species belonging to human flora skin such as Corynebacterium striatum, Corynebacterium jeikeium and Corynebacterium urealyticum have expressed multidrug-resistance can cause a wide range of disorders as bacteremia, endocarditis, septicemia and others invasive infections mainly in immunocompromised patients (Bernard 2012).

Resistance to fluoroquinolones has become common in some bacterial pathogens. Analysis of the sequences of the QRDR of the gyrA gene in isolates of C. striatum, Corynebacterium amycolatum, and Corynebacterium macginleyi have shown that resistance to fluoroquinolones is associated with mutations of a 
spontaneous nature in this gene and depends on the number of mutations and the type of aminoacid that has been substituted (Sierra et al. 2005; Eguchi et al. 2008; Alibi et al. 2017).

In this study, we investigated 14 multidrug-resistant isolates of C. striatum $(\mathrm{n}=7)$, C. jeikeium $(\mathrm{n}=4)$ and C. urealyticum $(\mathrm{n}=3)$ from blood $(\mathrm{n}=10)$ and catheter segments $(n=4)$, during the period of 48 months (Aug. 2009 - Aug. 2013) of 13 hospitalised patients attended in two hospitals located at the metropolitan area of Rio de Janeiro, RJ, Brazil. All isolates were deposited in the bacteria collection: Coleção de Bactérias do Ambiente e Saúde of Fundação Oswaldo Cruz (CBAS/FIOCRUZ—www. cbas.fiocruz.br).

The identity of isolates was confirmed by $16 \mathrm{~S}$ rRNA and rpoB genes sequencing (Baio et al. 2013). The antimicrobial susceptibility test by disk-diffusion method according to Brazilian Committee on Antimicrobial Susceptibility Testing (BrCAST) document showed that all isolates of $C$. jeikeium, $C$. urealyticum and three isolates of $C$. striatum were resistant to penicillin, gentamicin, clindamycin, erythromycin, rifampin and imipenem. Five isolates of $C$. striatum showed variable susceptible to gentamicin, rifampin and imipenem, but all isolates of corynebacteria were susceptible to linezolid, tetracycline and vancomycin. The minimum inhibitory concentration (MIC) using E-test strips (AB Biodisk, Sweden) for ciprofloxacin, levofloxacin and moxifloxacin was performed according to BrCAST document. Due to absence of levofloxacin breakpoints in this guideline, the interpretation of values was interpreted in accordance to criteria defined by BrCAST for Staphylococcus spp. (Alibi et al. 2017).

The sequences of the QRDR of the gyrA gene were compared to that of the quinolone-susceptible type strains C. striatum ATCC 6940, C. jeikeium ATCC 43734 and C. urealyticum DSM 7109 (Table 1). All type strains have codons for Ser-87 and Asp-91 in the QRDR region of the gyrA gene. The MIC for fluoroquinolones were compared to the mutations in QRDR of the gyrA gene. All C. striatum isolates showed mutations in the codon 87 , only two isolates showed double mutation in codons 87 and 91. Two $C$. jeikeium isolates showed MIC $>32 \mu \mathrm{g} / \mathrm{mL}$ for all fluoroquinolones tested probably due to novel mutations in the QRDR gyrA gene, where in the codon for Ser-87 changed to Ile-87 and the codon Asp-91 to Tyr91. The three $C$. urealyticum isolates showed double mutation in codons 87 and 91. Two isolates showed mutation of Ser-87 to Tyr- 87 and one isolate of Ser-87 toVal-87. The codon Asp-91 was changed to Ala-91 (two isolates) and Tyr-91 (one isolate). All $C$. urealyticum isolates showed $\mathrm{MIC}>32 \mu \mathrm{g} / \mathrm{mL}$ to ciprofloxacin, levofloxacin and moxifloxacin. All isolates Corynebacterium spp. with mutations in the codons 87 and 91 had the highest MIC for moxifloxacin.

Fluoroquinolones have been extensively used in the empirical treatment of urinary tract infections, including in Brazil (Hisano et al. 2015). These drugs accumulate in the organs of the body leading to the selection of spontaneous mutants in large populations that colonize the skin and mucous membranes, such as corynebacteria, which can cause nosocomial bacteremia (Sierra et al. 2005; Alibi et al. 2017). Studies have shown that increasing fluoroquinolones resistance rates in almost all bacterial species have limited empirical antimicrobial treatment options (Dalhoff 2012).

To our knowledge, no study comparing the mutations in the gyrA gene and the susceptibility to fluoroquinolones in C. urealyticum and C. jeikeium has been described. In summary, we report here the emergence of fluoroquinolone resistance in $\mathrm{Co}$ rynebacterium species isolated from blood and catheter segments with novel mutations at amino acid positions 87 and 91 in QRDR gyrA gene producing high levels of resistance to ciprofloxacin, levofloxacin and moxifloxacin. 
Table 1 Relationship between mutations in the QRDR of the gyrA gene and the MIC for Corynebacterium spp

\begin{tabular}{|c|c|c|c|c|c|c|c|c|c|}
\hline \multirow[t]{2}{*}{ Species } & \multirow{2}{*}{$\begin{array}{l}\text { Isolates/ } \\
\text { CBAS no }\end{array}$} & \multicolumn{2}{|c|}{ GyrA (amino acids) } & \multicolumn{3}{|c|}{ MIC $(\mu \mathrm{g} / \mathrm{mL})$} & \multicolumn{3}{|l|}{ Genbank no } \\
\hline & & $\begin{array}{l}\text { Position } \\
87\end{array}$ & $\begin{array}{l}\text { Position } \\
91\end{array}$ & CIP & LVX & MXF & gyrA & 16S rRNA & rрoB \\
\hline \multirow[t]{8}{*}{ C. striatum } & $\begin{array}{c}2130 / \\
\text { CBAS } \\
612\end{array}$ & Tyr & Asp & 2 & 1.5 & 0.75 & MG010352 & KJ855309 & KR010642 \\
\hline & $\begin{array}{l}2296 / \\
\text { CBAS } \\
615\end{array}$ & Phe & Ala & $>32$ & $>32$ & $>32$ & MG010359 & KJ855313 & KR010636 \\
\hline & $\begin{array}{l}2425 / \\
\text { CBAS } \\
620\end{array}$ & Phe & Ala & $>32$ & $>32$ & $>32$ & MG010366 & KM001911 & KR010631 \\
\hline & $\begin{array}{l}\text { 2023/ } \\
\text { CBAS } \\
618\end{array}$ & Val & Asp & $>32$ & $>32$ & 8 & MG010347 & JF342699 & JF342707 \\
\hline & $\begin{array}{l}\text { 2230/ } \\
\text { CBAS } \\
617\end{array}$ & Val & Asp & $>32$ & $>32$ & 8 & MG010354 & KJ855311 & KR010641 \\
\hline & $\begin{array}{l}2237 / \\
\text { CBAS } \\
616\end{array}$ & Val & Asp & $>32$ & $>32$ & $4-6$ & MG010355 & KJ855312 & KR010640 \\
\hline & $\begin{array}{l}\text { 2308/ } \\
\text { CBAS } \\
614\end{array}$ & Val & Asp & $>32$ & $>32$ & 6 & MG010360 & KJ934785 & KR010635 \\
\hline & $\begin{array}{r}\text { ATCC } \\
6940\end{array}$ & Ser & Asp & 0.094 & 0.19 & 0.125 & ACGE01000134 & ACGE01000134 & ACGE01000134 \\
\hline \multirow[t]{5}{*}{ C. jeikeium } & $\begin{array}{l}2325 / \\
\text { CBAS } \\
677\end{array}$ & Ile & Asp & $>32$ & $>32$ & $4-6$ & MH513932 & MH510232 & MH513925 \\
\hline & $\begin{array}{l}\text { 2509/ } \\
\text { CBAS } \\
681\end{array}$ & Ile & Asp & $>32$ & $>32$ & 4 & МH513935 & MH510235 & МH513928 \\
\hline & $\begin{array}{c}2443 B / \\
\text { CBAS } \\
679\end{array}$ & Ile & Tyr & $>32$ & $>32$ & $>32$ & MH513933 & MH510233 & MH513926 \\
\hline & $\begin{array}{l}\text { 2444/ } \\
\text { CBAS } \\
680\end{array}$ & Ile & Tyr & $>32$ & $>32$ & $>32$ & МH513934 & МH510234 & МH513927 \\
\hline & $\begin{array}{l}\text { ATCC } \\
43734\end{array}$ & Ser & Asp & 0.125 & 0.19 & 0.125 & ACYW01000075 & ACYW01000075 & ACYW01000075 \\
\hline \multirow[t]{4}{*}{$\begin{array}{l}\text { C. } \\
\quad \text { urealyticum }\end{array}$} & $\begin{array}{l}2260 / \\
\text { CBAS } \\
675\end{array}$ & Tyr & Ala & $>32$ & $>32$ & $>32$ & MH513936 & MH510236 & MH513929 \\
\hline & $\begin{array}{c}2287 \mathrm{~B} / \\
\text { CBAS } \\
676\end{array}$ & Tyr & Ala & $>32$ & $>32$ & $>32$ & MH513937 & MH510237 & MH513930 \\
\hline & $\begin{array}{c}2431 / \\
\text { CBAS } \\
678\end{array}$ & Val & Tyr & $>32$ & $>32$ & $>32$ & MH513938 & MH510238 & МH513931 \\
\hline & $\begin{array}{l}\text { ATCC } \\
43042\end{array}$ & Ser & Asp & 0.125 & 0.125 & 0.125 & NC010545 & NC010545 & NC010545 \\
\hline
\end{tabular}

$M I C$ minimum concentration inhibitory, $C I P$ ciprofloxacin, $L V X$ levofloxacin, $M X F$ moxifloxacin 
Acknowledgements This study was financed in part by Coordenação de Aperfeiçoamento de Pessoal de Nível Superior - Brasil (CAPES) - Finance Code 001, Fundação Oswaldo Cruz (Programa Inova Fiocruz/VPPCB-007-FIO-182-103), Conselho Nacional de Desenvolvimento Científico e Tecnológico (CNPq), Fundação de Amparo à Pesquisa do Estado do Rio de Janeiro (FAPERJ), Sub-Reitoria de PósGraduação e Pesquisa da Universidade do Estado do Rio de Janeiro (SR-2/UERJ).

Author's contribution Conceived o for designed study: VVV and ALMG Performed research: JNR and TBV Analysed data: JNR and PVPB Wrote the paper: JNR, PVPB and VVV.

\section{Compliance with ethical standards}

Conflict of interest All authors report no conflicts of interest to this article.

Ethical approval This study was developed in compliance with the Brazilian Government's Ethical Guidelines for research involving human beings (resolution of the National Health Council/Ministry of Health) and approved by the ethical research committee of HUPE/UERJ (CAAE: 01247512.3.0000.5259). The consent to participate was not required because all the investigated isolates were taken as a part of standard care (diagnostic purposes). The samples were not collected for research purposes.

Open Access This article is distributed under the terms of the Creative Commons Attribution 4.0 International License (http:// creativecommons.org/licenses/by/4.0/), which permits unrestricted use, distribution, and reproduction in any medium, provided you give appropriate credit to the original author(s) and the source, provide a link to the Creative Commons license, and indicate if changes were made.

\section{References}

Alibi S, Ferjani A, Boukadida J, Cano ME, Fernández-Martínez M, Martínez-Martínez L, Navas J (2017) Occurrence of Corynebacterium striatum as na emerging antibiotic-resistant nosocomial pathogen in a Tunisian hospital. Sci Rep 7(1):9704

Baio PVP, Mota HF, Freitas AD, Gomes DL, Ramos JN, Sant'Anna LO, Souza MC, Camello TC, Hirata R Jr, Vieira VV, Mattos-Guaraldi AL (2013) Clonal multidrug-resistant Corynebacterium striatum within a nosocomial environment, Rio de Janeiro, Brazil. Mem Inst Oswaldo Cruz 108:23-29

Bernard K (2012) The genus Corynebacterium and other medically relevant coryneform-like bacteria. J Clin Microbiol 50:3152-3158

Dalhoff A (2012) Global fluoroquinolone resistance epidemiology and implications for clinical use. Interdiscip Perspect Infect Dis. 2012:976273

Eguchi H, Kuwahara T, Miyamoto T, Nakayama-Imaohji H, Ichimura M, Hayashi T, Shiota H (2008) High-level fluoroquinolone resistance in ophthalmic clinical isolates belonging to the species Corynebacterium macginleyi. J Clin Microbiol 46:527-532

Hisano M, Bruschini H, Nicodemo AC, Gomes CM, Lucon M, Srougi M (2015) The bacterial spectrum and antimicrobial susceptibility in female recurrent urinary tract infection: how different they are form sporadic single episodes? Urology 86(3):492-497

Sierra JM, Martinez-Martinez L, Vásquez F, Giralt E, Vila J (2005) Relationship between mutations in the gyrA gene and quinolone resistance in clinical isolates of $\mathrm{Co}$ rynebacterium striatum and Corynebacterium amycolatum. Antimicrob Agents Chemother 49:1714-1719

Yoo G, Kim J, Uh Y, Lee HG, Hwang GY, Yoon KJ (2015) Multidrug-resistant Corynebacterium striatum bacteremia: first case in Korea. Ann Lab Med 35(4):472-473

Publisher's Note Springer Nature remains neutral with regard to jurisdictional claims in published maps and institutional affiliations. 